\title{
The Tyranny of Concepts: CUDIE (Cumulated, Depreciated, Investment Effort) Is Not Capital
}

\author{
LANT PRITCHETT \\ World Bank; Kennedy School of Government, Harvard University, 79 JFK Street, Cambridge, MA 02138
}

\begin{abstract}
The cost of public investment is not the increment to the value of public capital. Unlike with private investors, there is no plausible behavioral model in which every dollar that the public sector spends as "investment" creates economically valuable "capital." While this simple analytic point is obvious, it has so far been uniformly ignored in the empirical literature on economic growth, which uses-at best-cumulated, depreciated, investment effort (CUDIE) as a proxy for capital stocks. However, particularly for developing countries the difference between investment cost and capital value is of first-order empirical importance: government investment is half of more of total investment, and calculations presented here suggest that in many countries government investment spending has created little useful capital. This has implications in three broad areas. First, none of the existing empirical estimates of the impact of public spending has identified the productivity of public capital. Even where public capital has a potentially large contribution to production, public-investment spending may have had a low impact. Second, it implies that all estimates of total factor productivity in developing countries are deeply suspect as there is no way to empirically distinguish between low growth because of investments that create no factors and low growth due to slow productivity growth. Third, multivariate regressions to date have not adequately controlled for capital stock growth, which leads to erroneous interpretations of regression coefficients.
\end{abstract}

Keywords: capital, growth, productivity, public sector

JEL classification: $\mathrm{O} 40, \mathrm{O} 47, \mathrm{H} 50$

\section{Introduction}

I begin with an old joke, a personal story, and a striking example - each of which illustrate the basic conceptual issue with the valuation of public capital. The old joke: While on a foreign trip a government official of country A is visiting the penthouse apartment of his friend B, a bureaucrat of a poor country. After A admires the fine residence and furnishings, he says: "We're friends. Be honest with me B. I know that with your official salary you cannot possibly afford this. What gives?" Taking his friend to the window, B replies, "See that superhighway running through town? 10 percent." Some time later B has the occasion to visit the even poorer country of his friend A and finds himself in an even larger and more luxuriously appointed penthouse apartment. Says B, "I know your official salary must be even lower than mine, yet your house is much nicer. What gives?" Taking his friend to the window, A points and says, "See that superhighway running out into the jungle?" After straining his eyes for a minute B replies, "But there is no highway out there." "Exactly," says A with a wink. "100 percent." 
The personal story: In 1991 I traveled to an industrial estate for public enterprises in Tanzania. Even then the factories were dilapidated: the structures were mostly rotting hulks, there was little workable machinery, and few workers still bothered to show up. ${ }^{1}$ Later, in discussions with government officials back in the capital I was told the primary obstacle with privatization was that these factories I had visited were just too valuable. His logic was that because these factories had been very costly to construct (mostly financed with large official loans), they must be worth and had to sell for what they cost. But this made them too expensive for domestic entrepreneurs, and the government did not want to sell their valuable national assets to foreigners. By my sights he had exactly the opposite problem: the real problem was not finding buyers who could afford the firms; the real problem was that government couldn't afford to pay people to take them away. As ongoing enterprises the firms had negative value: the debts incurred for construction costs far exceeded the current value of the assets.

The striking example: Two steel mills were built by parastatals with government backing with investments of several billion dollars. One mill, Pohang Iron and Steel in Korea, is now a model of efficiency and a serious competitor in world steel markets. The other, Ajaokuta Steel in Nigeria, has spend upward of \$4 billion (U.S.) and has never been finished to its planned capacity, much less produced to that capacity. In December 1998, after the end of the previous military government, there emerged reports that $\$ 2$ billion had been siphoned off from the project into the coffers of various government officials.

Each of these illustrates the same problem with combining the standard national accounting practice of recording government investment at cost - not saleable value - with perpetual inventory accumulation to estimate "capital." To do so assumes that if the investment cost was the same (in the public or private sector, in two different countries, in irrigation or in nuclear power, or in two periods), then the increment to capital is the same-whether the investment spending was efficient or even productive. This uses the word capital for two completely different concepts. The idea of an accumulated input, not fully exhausted in a single production period, valued now for its future contribution to output, is a workable and useful concept. The idea of cumulated, depreciated, investment effort (CUDIE) is also a workable and useful concept. However, equating the two concepts (or even claiming one is an adequate empirical proxy for the other) by calling CUDIE perpetual inventory capital stocks is obviously and importantly false.

The next section illustrates the need for a positive model of government behavior to interpret the impact of public-sector investment spending on public sector capital. Section 3 argues that there is not and will not be any single such positive model that is applicable to all governments at all times. Section 4 assembles some data on the magnitude of the differences in public-sector efficacy. Section 5 examines the implications of ignoring differential investment efficacy for estimating the productivity of public capital and the erroneous policy recommendations that could emerge. Section 6 illustrates the implications of the mismeasurement of factor accumulation for existing decompositions of output/growth into factors and factor productivity. Section 7 briefly illustrates the implications for the growth regressions that are currently in such vogue and is followed by the conclusion. 


\section{Capital and Models of Investor Behavior}

Two issues in the measurement of capital affect both public and private capital. I want to acknowledge these and get them out of the way to focus on the distinctive problem with public investment.

First, economics has long made the distinction between the cost of a capital good, which is based only on the past, and the value of a capital good, which depends only on the future. Hayek's The Pure Theory of Capital (1941, p. 10) should have put to rest the idea "harmful ... to the theory of capital ... that particular capital items represented a definite value, independently of the use that could be made of them, a value which was apparently thought to be determined by the amounts 'invested' in them." The value of capital and cost of investment will diverge ex post for at least three reasons: relative price shifts, technological changes, and mistakes. Since the value of a capital good depends on expected future prices, not fully anticipated changes in relative prices will change the value of capital goods. These changes in relative prices can stem either from terms of trade changes ${ }^{2}$ or from policy reforms (for example, a decline in value of capital equipment devoted to import substitution following tariff reductions). Technological innovations create a process of "creative destruction" that reduces the value of existing capital stocks that embody old techniques due to innovation (Jaffee, 1986). Finally, even though private investors equate costs and expected value, when investing the private sector often makes (large) mistakes. The private sector will have its share of ex post white elephants either through underestimating costs or overestimating potential profits.

The second problem that affects both private- and public-sector capital, especially in cross-national comparisons, is that differences in the relative prices of investment goods will alter the relationship between investment spending and actual value of capital created (DeLong and Summers, 1992). Some countries have imposed large tariffs on imported capital goods and hence raised the relative price of investment goods. But this additional investment spending over and above international prices does not create any additional productive capital. However, since the Penn World Tables investment series are based on comparable prices of investment goods across countries, then CUDIE based on those series (such as King and Levine, 1994) should at least address, if not completely solve, that issue.

Having acknowledged the importance of the ex ante and ex post distinction and the importance of price differences in creating a divergence between the historical cost of investment and the current value of capital in both the private and public sectors, I want to focus on a different distinction. While there might be idealized conditions in which private investors equate current investment cost with future capital value ex ante, there is no plausible positive behavioral model of government as investor that would support associating measured public-sector CUDIE with the concept of public-sector capital. When governments are the investors, it unreasonable to assume that everywhere and always whatever governments have spent and called investment was exactly equal to the (potential contribution) to the value of current and future production - the increment to capital stock.

To formalize this, define the accounting cost of capital of capital good $C(X)$, which is what was actually spent (suitably deflated and discounted if costs are spread over several periods). The economic cost $E C(X, p)$ is defined as a technological concept: the minimum 
achievable cost of creating a capital good with given technologies at relative prices $p$. Let me define as the efficacy of investment the ratio of economic cost to accounting cost:

$$
E C(X) / C(X)=\gamma \text {. }
$$

This ratio will vary between 1 (when the minimum cost is actually achieved) and 0 and will typically be less than 1 as actual costs exceed economic costs.

If a capital good can be replicated (that is, it does not involve any rent or quasi-rent), the value of a capital good is at most its economic cost. Under some additional conditions and assuming a particular form of depreciation, ${ }^{3}$ this means that the basic equation for the accumulation of capital in the $i$ th country in the $s$ th sector $(G=$ government, $P=$ private) can be written as in equation (2):

$$
K_{t}^{i, s}=K_{t-1}^{i, s}-\delta^{i, s *} K_{t-1}^{i, s}+\gamma_{t}^{i, s *} I_{t}^{i, s} .
$$

Only a fraction $\gamma$ of the actual accounting cost of investment passes into the value of capital. There are no empirical or theoretical grounds for assuming that the public sectors everywhere (think of Tanzania, Nepal, Guyana, Russia, Syria, Paraguay, Laos, and so on) - are always efficient investors. Yet this obvious point is routinely ignored. To my knowledge $e v-$ ery cross-national estimate of physical capital is fundamentally based on, at most, a simple pair of formulas, where $s$ are sectors (in fact most calculations are just aggregate ignoring the public private distinction altogether):

$$
K_{t}^{i}=\sum_{s} K_{t}^{i, s}, \quad K_{t}^{i, s}=K_{t-1}^{i, s}-\delta^{s *} K_{t-1}^{i, s}+I_{t}^{i, s} .
$$

These formulas and a time series on investment(s) and an estimate of the stock(s) $K$ in some period allow the construction of a time series usually called perpetual inventory capital stocks - or usually just capital. ${ }^{4}$ The behavioral model embedded in the universally used equation (3) - and hence in all the existing empirical literature that uses CUDIE as a proxy for capital ${ }^{5}$-is full public-sector efficiency, $\gamma_{t}^{i, G}=1$, for all $i$ and for all $t$ : that all governments are always cost minimizing.

CUDIE has no priority as a capital stock estimate but is just a very special case. Once formalized it is obvious the restrictive assumption on investment efficacy to reach the special case of equation (2) (CUDIE) from the general equation (3) is false. Not just in investment but in a wide variety of activities (from health to education to tax collection to policy formation) governments are frequently less than fully effective. Moreover, some governments much less effective than others.

Ignoring this valuation problem might be innocuous in some applications if the effect is empirically small or if the effect is uniform across the unit of comparison (countries or time). But there is no reason to believe either of these conditions hold - and certainly not that they hold universally. Valuation of public investment might not be a first-order problem in estimating capital stocks where government is a small fraction of investment and is reasonably effective (such as in the United States or Japan). However, where government is either the major investor or is ineffective (or both - as in many countries in Africa, Middle East, South Asia, Southeast Asia, and Latin America), the CUDIE versus capital gap may overwhelm nearly all other aspects of measurement. 


\section{A Positive Model of Government Investment Efficacy}

To build a capital stock one needs to impose a value for investment efficacy, but to do so one needs a positive model of government behavior. The efficacy of investment $\gamma(\cdot)$, which links investment cost and capital value, is not a fixed parameter but an endogenous outcome. One cannot assume that investment equals the increment to capital without a behavioral model in which investors seek to minimize cost. Under some stringent conditions individual profit-maximizing actors will be cost-minimizing investors and hence create a tendency for $\gamma$ to approach 1 . These stringent conditions are unrealistic even in the private corporate sector and agency problems - that cause less than full efficiency in private organizations, including not minimizing the costs of investment-have received a great deal of attention in the literature (Milgrom and Roberts, 1992).

While is not the case that governments will everywhere and always be less efficient than the private sector, there are three considerations that suggest the agency problems in the public sector will make it qualitatively more difficult for citizens to monitor and control costs of investments by their governments than for shareholders to discipline managers. These three are the state is a monopoly, there is no market for the ownership, and the nature of public-sector production.

The state intrinsically exercises a monopoly on institutionalized coercive power-police, judiciary, and military - within its territory (this is roughly Webber's definition of the state). This exacerbates agency problems in five ways. First, the state has the ability to extract resources for investments irrespective of the citizen's views of the profitability of the capital to be created. Hence there is no legal voluntary option for citizens not to invest their funds. Second, the monopoly of violence also implies that the government can often put direct restrictions on the individual citizen's ability to monitor the government, through restricting information, curtailing individuals' ability to complain publicly, and so on. ${ }^{6}$ Third, because the state is intrinsically a monopoly, it is also a monopolist in many of the services it provides. Without multiple providers of roads, electricity, telecommunications, water, defense, judiciary, and so on, comparisons of cost and efficiency are difficult if not impossible. ${ }^{7}$ Fourth, the intrinsic monopoly of government also implies that new startups are not a viable mechanism for responding to ineffective states. Unlike giant firms overtaken by entrepreneurs who started small and through superior performance attracted resources that allow them to expand, one cannot start a competing "state" in the proverbial garage. Fifth, in the absence of established and widely respected procedures for management changes in government, these frequently occasion the use of force and are costly: hostile takeovers of governments tend to be very, very, hostile.

The second major element that makes agency problems more difficult when citizens monitor governments intrinsically than when the monitor corporations is that, unlike corporations, "ownership" (the claims to the residual value of assets) is not traded. This creates a signaling problem and an incentives problem. Anyone disgruntled with the management of General Motors or IBM can use an "exit" option and sell their claim. If enough people do this and share prices fall, this creates a useful signal and a mechanism for even casual observers to monitor management performance and its implications for the future. If there were a market for transferable claims to, say, Nigerian or Nepalese or German citizenship 
and the "citizenship" price began to plummet because market analysts thought current management was making poor investments, this would certainly attract the attention of existing citizens and create immediate pressures - even before the actual consequences emerge. But there isn't such a market. In addition to the lack of signaling, the lack of a "citizenship" market also implies that managers of the government cannot be explicitly offered "highpowered" incentives linked to their jurisdictions performance as is frequently the case with top management of corporations. ${ }^{8}$

The third major difficult in monitoring government investment performance is that many public-sector investment are in the public sector because they are "public goods" or, for one reason or another, the capital would not be provided in appropriate amounts by the private sector. The contribution of public-sector capital may not be privately appropriable, which implies that, unlike private capital, one cannot look to any actual "market" for the capital goods that the public sector produces for a proper valuation of the capital created and hence immediately detect excess costs.

Because I suspect it is impossible, I will not attempt to construct a single general model of government investment behavior but rather only indicate the features of a class of plausible agency models might have and their implications for measuring capital stocks. "Government" behavior is a complex problem of many agents (the citizens or voters) who attempt to constrain the actions of relatively few principals (the political leaders), who typically interact among themselves in complex ways (for example, executives versus legislatures), and these leaders as principals in turn have to control over another set of agents (the government's employees).

Even a simple class of models where all of the internal agency problems are ignored and the government is treated as a single actor needs several elements: an actor called $G$ (government) and another set of actors called $C$ (citizens). $G$ and the $C$ have objective functions and beliefs. I assume the objective function of $G$ increases with the gap between actual and economic costs. This could arise in many forms: venality, in which $G$ receives direct money payments for personal benefit from the granting investment project contracts (or other government purchases) (Shliefer, 1993; Shliefer and Vishny, 1998); patronage, in which $G$ raises costs to provide extra payments to others (either political supporters or employees); or the more common, shirking, in which $G$ does not expend effort (which entails disutility) to reduce costs.

Since the objective function of the agents $C$ is likely to be decreasing in the gap between actual and economic cost, the model would have to have mechanisms whereby $C$ might be able to impose constraints on the behavior of $G$. Conceptually, these "accountability" mechanisms can be decomposed into the probability of detection of cost overruns, the expected "punishment" conditional on detection (which is itself a combination of probability of punishment on detection and the magnitude of punishment when detected). These constraints on government behavior are a key element but also the most difficult to model convincingly as they vary across countries' institutional and political environments and depend on differing institutional control mechanisms (such as budget agencies, effectiveness of audit, and oversight commissions).

In this class of agency model $G$ picks the level of actual capital-good cost to maximize its objective function, given its beliefs about the constraints it faces from $C$. These models will 
predict that governments will choose as their "optimum" actual-cost amounts that exceed economic costs. So $V^{*}(\cdot), P^{*}(\cdot)$, and $C^{*}(\cdot)$ are the functions that map from $G$ 's objective function and constraints (represented by factors $Z$ ) into the optimally chosen additional costs due to venality, patronage, and shirking. Hence total excess costs are actual costs $C^{*}(x, Z, p)$ less economic cost:

$$
C^{*}(x, Z, p)-E C(x, p)=V^{*}(x, Z)+P^{*}(x, Z)+S^{*}(x, Z) .
$$

In an general agency framework excess cost of investment $\gamma$ would be a function of underlying determinants of both government objectives (such as discount rates) and of the control of citizens $C$ over the government agent (such as freedom of the press, voter choice, information availability and budget disclosure, judiciary independence and competence) ${ }^{9}$

$$
\gamma_{i, t}=\gamma^{*}\left(Z_{i, t}\right) .
$$

Any particular model within this class of agency models would make three predictions. First, the range in the degree of citizen control over governments observed around the world is enormous - from totalitarian regimes in which financial information is a state secret and questioning government actions leads to prison (or worse) to democracies in which competition for power and public scrutiny are intense and effective. This large variance in the $Z$ 's in the model will imply that a prediction that, at any point in time, the degree of investment efficacy in some countries will be much higher than in other countries:

$$
\text { For some/many countries } i, j \quad \gamma_{i, t}^{* G} \ll \gamma_{j, t}^{* G} \text {. }
$$

Second, over time in countries there will be periods of greater and lesser investment efficacy as the constraints and opportunities for benefiting from excess investment change:

$$
\text { For some country(ies) } i, \quad \exists n \text { such that } \gamma_{i, t-n}^{* G} \ll \gamma_{i, t}^{* G} .
$$

Third, given the discussion above detailing the many additional complications in the agency relationship for governments versus firms as investors, positive models would predict that government investment efficacy for many countries would be less than the private sector. Moreover, in at least some countries investment efficacy will be much less than one for many countries:

$$
\text { For some country(ies) } i, \quad \gamma_{i, t-n}^{* G} \ll \gamma_{i, t}^{* P} \leq 1 .
$$

I am not certain how exactly to model the determinants of investment efficacy across countries - and suspect there is no single general model. But I can be reasonably certain that any plausible positive behavioral model of government will not predict what is presently the universal assumption made in the construction of all capital stock estimates - that all government investments are always equally and fully efficient:

$$
\text { [CUDIE assumption] } \quad \gamma_{i, t}^{* G}=\gamma_{j, t}^{* P}=1 \quad \forall i, j, t .
$$

\section{Empirical Estimates of Differences in Investment Efficacy Across Countries}

What kind of evidence can be provided on the above hypotheses about public-sector investment efficacy? Even casual observation reveals that white elephants-investments 
Table 1. Economic rates of return on government investment projects financed by the World Bank.

\begin{tabular}{lccc}
\hline & $\begin{array}{c}\text { Number of } \\
\text { Projects }\end{array}$ & $\begin{array}{c}\text { Cumulative } \\
\text { Investment } \\
\text { (millions) }\end{array}$ & $\begin{array}{c}\text { Median ex post } \\
\text { Economic Rate of } \\
\text { Return }\end{array}$ \\
\hline An African country & 31 & 915 & 0 \\
A South Asian country & 88 & 19,718 & 16.5 \\
An East Asian country & 41 & 8,233 & 19.5 \\
All countries & & & 14.1 \\
\hline
\end{tabular}

Source: Author's calculations from World Bank's Operations Evaluation Department database.

with huge costs and little value-are common and more common (and more spectacular) in some places and times than others. The Ajaokota mill is not the only problematic facility in the world: the Lazaro Cardenas mill in Mexico has similar cost-overrun and production-underrun problems. A nuclear power plant constructed in the Philippines under Marcos had an investment cost of more than $\$ 2$ billion but almost certainly will never be commissioned - and so has minimal value as capital. The World Bank financed Morogoro Shoe factory in Tanzania cost $\$ 40$ million - and peak production was 4 percent of planned capacity. The list could go on and on. However, there are very good reasons that it is difficult to go beyond anecdotes and provide more reliable quantitative estimates of investment efficacy. Governments have every incentive to make excess costs as difficult to observe as possible. Not having solid, reliable, cross-national evidence on excess costs is to some extent a predictable outcome of the agency approach. So, while I will present four sources of evidence that investment-efficacy differences are large between countries and between the public and private sectors, I admit up front that each is indirect and not entirely satisfying.

A first piece of evidence on differential public-sector investment efficacy comes from cross-national data on ex post economic rates of return on World Bank - financed investment projects. ${ }^{10}$ The World Bank finances, but does not implement, government projects in many countries and uses the same procedures and staff in every country. There are arguments that the realized differences in returns across countries indicate varying government investment efficacy (Isham et al., 1996). Table 1 shows the return on investments financed between 1973 and 1991. The median return across all those countries with nine or more projects was 14.1 percent, but the statistic interesting for current purposes is that variation across countries: the range was from 0 to 25 percent. In one African country the World Bank lent nearly $\$ 1$ billion over this period to finance 31 projects that achieved a median rate of return of zero. In contrast, the $\$ 8.2$ billion lent to finance government projects in one East Asia country earned a median return of 19.5 percent. While this evidence shows clear differences in returns across countries, it cannot distinguish among the causes of differential investment returns - excess investment costs, inefficient operation of facilities once created, ex post price shocks, and so on.

Second, Table 2 reports the cost per kilometer of constructing similar roads in various countries derived from World Bank project documents. These data show enormous differences: cost per kilometer are 5 to 10 times higher in the high- than low-cost countries. 
Table 2. Costs of construction of a kilometer of similar road in selected countries in 1985 dollars.

\begin{tabular}{lclr}
\hline Country & High-Cost Countries & Country & Low-Cost Countries \\
\hline Honduras & $\$ 771,068$ & Chile & $\$ 143,840$ \\
Ethiopia & 721,160 & India & 143,306 \\
Guatemala & 631,965 & Costa Rica & 131,966 \\
El Salvador & 540,632 & Philippines & 111,343 \\
Pakistan & 434,650 & Uruguay & 95,440 \\
Nigeria & 426,839 & Korea & 92,072 \\
& & Sri Lanka & 5,277
\end{tabular}

Notes: Average cost: $\$ 287,350$. Brazil and Argentina were not included in the high and low lists because of doubts about appropriate deflation and exchange-rate conversion under hyperinflation. Source: Canning and Fay (1996).

Again, this evidence is not conclusive as, even these cost estimates were for a standard type of road, some large fraction of the differences in costs is potentially accounted for by technical differences (like the location of the road).

Third, if governments differed in the efficacy of their investment, one would expect the estimates of the impact of public CUDIE to be very different for different countries. Unfortunately, there are few good estimates of the productivity of public capital, and those few are of limited comparability. ${ }^{11}$ But these few studies do show huge differences across economies. Estimates of the returns to public capital in Mexico are between 5 and 7 percent (versus 14 to 18 for private capital) (Shah, 1992), while estimates from two East Asian economies (in which efficacy is thought to be high) are 77 percent in Taiwan (China) and 51 percent in Korea (Uchimura and Gao, 1993). While these differences could be interpreted as extremely large differences in the productivity of capital across countries (perhaps public capital in Mexico has a very low marginal product), one can equally legitimately interpret these differences as reflecting differences in the efficacy of public sector investment $\left(\gamma_{g}\right)$ between the countries so that equivalent amounts of spending produce different amounts of capital.

Fourth, there is evidence on the gap between returns to public- and private-sector investment in individual countries. I present evidence only for India because there are independent estimates and because in India there are public enterprises in the manufacturing sector so the problems of public-sector output valuation are not paramount. Rajaiah (1989) finds that the return on public capital employed in "goods-producing sectors" in the 1967 and 1968 period to the 1973 and 1974 period (for which comparable data were available) was only 3.9 percent versus 24.9 percent in the private sector - a ratio of six to one. Joshi and Little (1994) use an alternative, indirect, calculation using the relationship between growth rates, investment rates, and capital shares to calculate the returns to investment in these sectors in India over the period 1960 to 1975 and the period 1976 to 1986. As shown in Table 3 they find the return to investment in public-sector manufacturing in the latter period was 5.2 percent, while the return in private-sector manufacturing was more than four times higher, at 22.6 percent. Again, this evidence cannot distinguish among various possible explanations 
Table 3. Alternative calculations of the returns to investment in public and private sectors in India.

\begin{tabular}{|c|c|c|c|c|c|c|c|}
\hline \multirow[b]{3}{*}{ Period } & \multicolumn{3}{|c|}{$\begin{array}{l}\text { Return on Capital employed from } \\
\text { Firm Accounts (Rajaiah, 1989) }\end{array}$} & \multicolumn{4}{|c|}{$\begin{array}{l}\text { Inferred from contribution to growth } \\
\text { (Joshi and Little, 1994) }\end{array}$} \\
\hline & \multirow{2}{*}{$\begin{array}{c}\text { Goods } \\
\text { Producing } \\
\text { Public } \\
\text { Enterprises }\end{array}$} & \multirow[b]{2}{*}{$\begin{array}{l}\text { Private } \\
\text { Sector }\end{array}$} & \multirow[b]{2}{*}{$\begin{array}{c}\text { Ratio } \\
\text { Private/ } \\
\text { Public }\end{array}$} & \multirow[b]{2}{*}{$\begin{array}{l}\text { Whole } \\
\text { Public } \\
\text { Sector }\end{array}$} & \multicolumn{3}{|c|}{ Manufacturing } \\
\hline & & & & & Public & Private & $\begin{array}{c}\text { Ratio } \\
\text { Private/ } \\
\text { Public }\end{array}$ \\
\hline 1960 s and 1970 s & 3.9 & 24.9 & 6.4 & 5.4 & 2.1 & 11.1 & 5.3 \\
\hline 1976 to 1986 & & & & 6.2 & 5.2 & 22.6 & 4.3 \\
\hline
\end{tabular}

Source: Rajaiah (1989, tables 3.5 and 6.1 to 6.10); Joshi and Little (1994, table 13.4, estimates based on adjusted labor quality).

of lower public-sector returns (such as excess costs, excess depreciation, and inefficient operation) or a low marginal product of additional public capital - but is consistent with much lower government than private investment efficacy $\left(\gamma_{g} \ll \gamma_{p}\right)$.

Fifth, the firm-level counterpart of CUDIE is inflation adjusted, economically depreciated, cumulative investments in the firm. This suggests that a good indicator of public-sector investment efficacy is to compare what public enterprises producing private goods in a competitive environment would sell for relative to their CUDIE. ${ }^{12}$ In particular, this would distinguish between the "no capital" from the "badly used capital" explanations of the low output impact of public investments. If the reason for low output from public capital is simply low productivity under public-sector management, then public firms could sell for near their CUDIE (and perhaps much more than their annualized current profit stream). ${ }^{13}$ If, on the other hand, the investment spending has not produced economically valuable assets, then the privatization value of those assets will be much less than their CUDIE. However, in spite of the spate of privatizations over the last decade, this remains largely a thought experiment. I have not been able to collect any systematic concrete information of this type, but there are striking examples. ${ }^{14}$ The total net revenues from privatizing East German assets was negative $\$ 200$ billion. While the negative receipts indicate other factors - such as obligations on new owners - this nevertheless indicates the low value of the assets created from decades of investment (Boycko, Shliefer, and Vishny, 1993). While many developed countries have derived substantial revenues from privatization efforts, in most African countries the "privatizations" have either been liquidations or selling franchise rights rather than fixed assets and have generated very little net revenue.

The conceptual distinction between public-sector CUDIE and the value of public capital is clear. That there is no general positive behavioral theory of government behavior that would justify a universal prediction of cost minimization is also clear. This section has shown that, while there is no single piece of conclusive evidence, there is at least suggestive evidence that the efficacy of investment varies widely across countries and has often been quite low, much lower than in the private sector. The next three sections address the implications of these differences in public-sector investment efficacy, first for estimating the returns to public-sector capital, next for decomposing growth into "productivity" and "factor accumulation," and finally for understanding growth determinants. 


\section{Productivity of Public Capital and Policy Recommendations}

Is there too much or too little public capital? Is there too much of one type (roads) and not enough of another (schools) or perhaps vice versa? These are difficult questions to answer because, as discussed above, it is impossible to value public capital through a market, and many types of public capital contribute to production indirectly through reductions in costs or increases in productivity of private production. Often the only way to estimate the impact of some types of public-sector capital is at an aggregated level, and many empirical studies have used cross-national data on public-sector investment spending to examine whether, and what types, of government spending are "productive." However, whenever these studies rely on CUDIE as their proxy for capital, this approach may falsely conclude that "public capital" is unproductive when in fact public capital would be very productive but the investment efficacy is low-conclusions that have different policy implications.

\subsection{A Basic Production Function with Public-Sector Capital}

Start with a simple one-good $(Y)$ production function specification that distinguishes private $K_{p}$ and public $K_{g}$ ( $g$ for "government") capital stocks and allows for a separate productivity parameter for public $A_{g}$ and private $A$ production. What enters the production function is public capital (the true stock of capital available) and also how well that stock is used $\left(A_{g}\right)$ to produce a flow of "public capital services":

$$
Y=F\left(A, K_{p}^{\alpha_{p}}, K_{g}^{\alpha_{g}}, A_{g}\right) .
$$

Now suppose that only a fraction $\gamma^{G}(\cdot)$ of public investment actually creates useful public capital (the equation should also reflect that depreciation is also a behavioral, not technological, parameter but, again, I leave this aside). Then the capital stock growth is

$$
\hat{K}_{g}=\gamma^{G}(\cdot)^{*}\left(I_{g} / Y\right)^{*}\left(Y / K_{g}\right)-\delta_{g} .
$$

When this definition of capital growth is substituted into a log-linearized (such as quasiSolow $)^{15}$ expression for growth rates of output, the coefficient on public investment in the growth equation is the product of the production function parameter $\alpha_{g}$ and the efficacy of investment coefficient $\gamma^{G}()$ and the inverse of the capital/output ratio $\kappa_{g}$. Alternatively, the coefficient on public-sector CUDIE growth is $\alpha_{g}^{*} \gamma^{G}(\cdot)$ :

$$
\hat{y}_{t, t-n}^{i}=\alpha_{g}^{*}\left(\gamma_{i, t, t-n}^{G}(\cdot)^{*}{\frac{I_{g}}{Y}}^{*} \kappa_{g}-\delta_{g}\right)+\alpha_{p}^{*}\left(\gamma_{i, t, t-n}^{P}(\cdot)^{*} \frac{I_{p}{ }^{*}}{Y} \kappa_{p}-\delta_{p}\right)+\hat{A}+\hat{A}_{g} .
$$

A growth regression (or any other empirical procedure) limited to observing outputs and investment inputs cannot separately identify the technological productivity of public capital $\alpha_{g}$ and the public-sector efficacy of investment $\gamma^{G}(\cdot)$.

This is bad. This is not merely a problem of bias in the estimate of the productivity of public capital $\alpha_{g}$ but of identification. Neither time-series nor cross-unit regressions (or any other statistical procedure) based on observing public-sector investment are able estimate the parameter $\alpha_{g}$ at all. Even if $\gamma$ were fixed-over time or across units of observation - the 
coefficient CUDIE from a growth regression is still at best an estimate of $\gamma^{G *} \alpha_{g}{ }^{16}$ (and there is, of course, no guarantee once recovers even a consistent estimate even of that).

But its worse than that. Since $\gamma^{G}()$ is not a parameter but a behavioral outcome, there is no reason to expect it is constant either over time or across countries. Assume that there were a universal positive model of investment efficacy and, for simplicity, that it was determined completely by some variables $Z$, and that those were included linearly in the growth equation. Merely inserting these $Z$ (such as "extent of corruption" or "quality of bureaucracy" or some additional variables thought to be related to government efficacy) into the linear growth regression does not solve the identification problem on public investment. It would still be the case that the regression of growth on investment recovers, at best, $\bar{\gamma}^{G}(z)^{*} \alpha_{g}$ (the output effect of investment evaluated at average efficacy) but not $\alpha_{g}$. To estimate the productivity of public capital from investment spending the investment efficacy would have to be completely and correctly specified.

Table 4 reports two illustrative growth regressions, which is meant to be typical of the hundreds in the literature, one of which is a simple growth accounting exercise that regresses growth on (potentially endogenous) investment rates and another of which adds a set of "policy" control variables. ${ }^{17}$ If we assume that public capital's share in output is proportional to its share in total investment, then we can use the estimated coefficient to infer the average relative effectiveness of public investment:

$$
\frac{\gamma_{g}}{\gamma_{p}}=\frac{\beta_{g} / \alpha_{g}}{\beta_{p} / \alpha_{p}} .
$$

The estimates derived from this approach reported in Table 4, indicate a relative output effect of public investment 50 to 60 percent that of private investment - for instance, in the first regression,

$$
\frac{\left(\frac{.119}{.089}\right)}{\left(\frac{.229}{.109}\right)}=.63 .
$$

One interpretation is that this represents lower productivity of public capital. But this same evidence is consistent with a very high productivity of public-sector capital but much lower government than private investment efficacy (in this sample) so a given amount of investment spending creates less capital in the public sector than in private sector. The main point is that from the regression coefficients on investment $(\beta \mathrm{s})$ one can make assumptions about investment efficacy to make inferences about the productivity of public capital, or vice versa, but the regression coefficients alone do not identify either.

Since nearly all of the previous empirical literature on productivity of public capital has relied either on expenditures or cumulative investment flows to estimate capital stocks, this critique leads to fundamentally different interpretations of the results. ${ }^{18}$ Rather than drawing inferences from estimates about the effect of public capital (or the optimal effect of any kind of expenditure) as if one were recovering estimates of a "production function," it is equally (or perhaps more) plausible that empirical results differences in investment efficacy across countries, especially when countries with extremely different types of governments are included in the same analysis. 
Table 4. Cross-national growth regressions with public and private investment separately.

\begin{tabular}{lcc}
\hline & $\begin{array}{c}\text { Without "Policy" } \\
\text { Variables }\end{array}$ & $\begin{array}{c}\text { With "Policy" } \\
\text { Variables }\end{array}$ \\
\hline Private investment share of GDP & -22.3 & -22.3 \\
Consolidated public-sector investment share of GD & $-(6.41)$ & $-(6.29)$ \\
Ln initial income & -11.5 & -9.35 \\
Primary enrollment rate & $-(2.82)$ & $-(2.09)$ \\
& -0.42 & -.82 \\
Secondary enrollment rate & $-(1.17)$ & $-(2.25)$ \\
Dummy for 1960s & -.19 & -1.0 \\
& $-(.20)$ & $-(1.03)$ \\
Dummy for 1970s & -2.0 & -.3 \\
& $-(1.49)$ & $-(.203)$ \\
Dummy for Sub-Saharan Africa & -3.1 & -2.49 \\
& $-(5.78)$ & $-(4.32)$ \\
Dummy for Latin America and the Caribbean & -2.3 & -2.1 \\
& $-(6.08)$ & $-(5.97)$ \\
Ratio M2/GDP & -1.2 & -1.5 \\
& $-(2.42)$ & $-(2.90)$ \\
Government consumption/GDP & -1.6 & -1.68 \\
& $-(3.54)$ & $-(3.53)$ \\
$N$ (observations) & & -2.2 \\
Adjusted $R 2$ & & $(2.01)$ \\
Ratio of regression coefficient on public-sector in- & -8.4 \\
vestment divided by public investment share in & -.63 & $-(2.41)$ \\
GDP over coefficient on private investment over & & -.551 \\
private-sector investment share of GDP & & -.51 \\
\hline
\end{tabular}

Note: Data is taken from Easterly and Rebelo (1993). $t$ statistic in parentheses. Constants are included but not reported. The average private investment shares used in the calculation in the final row are $10.9(\mathrm{col} \mathrm{1)}), 11.0(\mathrm{col} 2)$, and the public investment share is $8.9(\mathrm{col} 1)$ and 8.9 ( $\mathrm{col} 2)$.

\subsection{Policy Advice on Public-Sector Investment}

From an empirical finding that the impact of public CUDIE on output was small, one might be tempted to recommend that the public sector should invest less since the productivity of public "capital" is low. But this is obviously wrong, in two senses.

First, policy recommendations clearly must differ across countries (and time). An empirical finding that "public investment" is not related to performance can either mean that (1) countries have overinvested in public capital so its marginal product $\left(\alpha_{g}\right)$ is very low, (2) public capital is very productive but the average effectiveness of public investment in creating public capital $\left(\gamma^{G}\right)$ is very low, (3) that public capital has been created effectively but used badly (low $A_{g}$ ), or (4) any combination of the three. Cross-national regressions recover, at best, some "typical" $\gamma^{G_{*}} \alpha_{g}$, but the true $\gamma^{G}$ or $\alpha_{G}$ for a given country could be much higher or much lower. Examining cross-national regressions and recommending that 
Chile or Korea not build roads because the observed productivity of public CUDIE in roads is low in a sample that includes Tanzania or Myanmar is clearly wrong(headed).

Second, imagine the decision tree for an economist (acting altrusitically with a benign social welfare function as the objective function) who asks: "Should I recommend spending $Y$ dollars of public sector resources to create capital good $X$ ?" The first question is whether $X$ is in a sector where there is some rationale for investment from the public sector. If the answer is no, stop. The next question is, even if there is a scope for public-sector intervention, whether the appropriate solution is direct provision or regulatory or some type of publicly subsidized procurement. This is an analytically difficult (and hence often ignored) question as the answer will vary from country to country and sector to sector. Suppose direct provision is appropriate. The next question is whether the present efficacy of spending $Y$ dollars to create capital would be high or low. If the roads or education or irrigation ministry is completely corrupt or ineffective (low $\gamma$ ), then prior to the investment decision the question is whether there are reforms capable of increasing efficacy. If there are reforms that would alter incentives so as to raise $\gamma$, then perhaps those should be pursued first before expanding investment.

Only after addressing all these questions does one arrive at the question of whether the marginal product of additional public-sector capital is high enough to justify additional investment in the capital good $X$. If public-sector investment efficacy is abysmally low $(\gamma \cong 0$ ) with no prospect for reform, then even if the marginal product of additional public capital would be very high, ${ }^{19}$ our hypothetical economist might still recommend no investment spending. Conversely, if public-sector efficacy is high $\left(\gamma^{G} \cong 0\right)$, then a much lower productivity of public capital could justify the investment. ${ }^{20}$

\section{Problems with Existing Decompositions of Growth}

There is a powerful intuition behind decomposing output per worker into that part "due to" how much "stuff" each worker uses and how much is "due to" how well that "stuff" is used. Of course, how exactly to define "stuff" and "due to" is precisely the subject of much of the growth literature debate. But no matter how the production function is specified, this decomposition approach will be badly wrong if how much productive "stuff" is actually out there is badly mismeasured.

Suppose one is comparing the output per worker of Tanzania and the United States. In 1985 relative outputs (in purchasing power adjusted units, $\mathrm{P} \$$ ) were 35 to one while CUDIE stocks were only 38 to one. If one plugs this into any production function model, then one can begin to ask questions like, "Are the differences in A implied reasonable?" or "How high would the share of capital need to be if $A$ were the same?" and "What about the other less material 'stuff' like human capital?" and so forth. However, for the United States CUDIE is likely a reasonably good estimate of the amount of physical capital available, but in Tanzania since the government has been both a major source of investment and has almost certainly had very low efficacy in that investment, CUDIE almost certainly dramatically overstates the physical capital actually available to augment production in Tanzania. Therefore, no matter how complex and sophisticated the theorizing, the whole line of reasoning fails empirically because $K$ is badly measured by CUDIE. The decomposition of output into 
"stuff" (factors) and "using stuff well" (productivity) works only if at least one of the two can be accurately measured. The failure of CUDIE as a proxy for capital has implications for both growth decompositions and for interpreting growth regressions.

If CUDIE substantially overstates actual capital, then this changes, potentially dramatically, the interpretation of "the residual," which is usually defined to be total factor productivity (TFP). The implications of a reinterpretation of the "residual" from total factor productivity to mismeasurement of factor accumulation can be explored by following a simple three-step procedure (data and procedure are documented in the working paper version appendices, available on request).

First, I construct an entirely standard set of estimates of TFP growth over the 30-year period 1960 to $1990^{21}$ by subtracting off from per worker output growth the capital share $\left(\alpha_{k}=.4\right)$ times growth in per worker CUDIE and the human-capital share $\left(\alpha_{h}=.3\right)$ times growth in human capital per worker:

$$
T F P_{i}=\hat{y}_{i}-\alpha_{k}^{*} C U \hat{D} I E_{i}-\alpha_{h}^{*} \hat{h}_{i}
$$

While there are many variants on this formula in implementation (choice of data for CUDIE, shares of physical and human capital, mapping growth of "years of schooling" to "human capital" growth, functional form), the present estimates are similar to the many others that have been constructed.

In these estimates more than half of developing countries ( 55 percent) have total TFP growth over the entire period less than zero. In more than a quarter of developing countries measured TFP growth is less than negative 1 percent per annum.

There are three possible interpretations of these incredibly low estimates of TFP. One could argue that in these countries there has been no technical progress at all for 30 years, so that even though the world production possibilities frontier has shifted out, somehow these countries possibilities not only did not grow but actually were shrinking. An alternative is that although the frontier shifted out and there was factor accumulation, these countries were somehow getting less and less productive in using existing factors. But a different interpretation is that much of the factor accumulation measured by CUDIE is just fictitious. The "stuff" supposedly reflected in adding up spending on investment just is not there as productive capital: CUDIE overstates capital growth and hence understates TFP.

This leads to a second step, which is to assume that there was some minimum growth rate of the actual "technical progress" - the expansion of the production function frontier - that was available to all countries and that (while countries were often far from the frontier in terms of productive efficiency) this gap was constant. For most developing economies one would have thought there would be some "advantage of backwardness" and that their PPF would growth faster than that of the leading countries as they closed the technological gap. Therefore, one assumption on minimum available technical progress is that it was 1 percent per annum (roughly the OECD average). In any case, the trend in technical progress should not be less than zero (in any case steady-state technical progress cannot be less than zero).

In the third step I scale back the growth of factor accumulation to be consistent with the observed rate of growth of output and the assumed lower bound on the growth of TFP. That is, in some countries observed factor accumulation is "too high" to be consistent with observed output growth (which if often negative) and a minimum rate of technical progress. 
I call this scaled-down factor growth the "implied" rate of factor accumulation. In equations, where $\tilde{f}$ and $\tilde{y}$ are the observed percent per annum growth of per worker factors (weighted by the shares) and output, the implied rate of factor accumulation $(\hat{f})$ is

$$
\hat{f}=\begin{aligned}
& \hat{f}=\tilde{f} \text { if } T F P \geq T F P_{\min } \\
& \hat{f}=\tilde{y} \text { if } T F P<T F P_{\min } .
\end{aligned}
$$

While the focus of this article is the possible overstatement of factor accumulation due to lack of public-sector efficacy in investment, in this illustrative exercise I cannot isolate this particular component, for three reasons. First, there is no data on consolidated public-sector investment (including parastatals) for this large cross-national sample so it is impossible to scale back differentially government and private investment. Therefore, if private investment efficacy is higher than public, then aggregate efficacy would be higher than public-sector efficacy. Second, this exercise cannot distinguish among all of the possible explanations of deviations of "capital" from CUDIE (revaluation due to price changes, excess depreciation, technology shocks, and so on). If all of the difference between observed CUDIE and implied factor accumulation were attributed to lower public-sector efficacy, then this would understate investment efficacy. Finally, there are two variants of the calculation, depending on whether in equation (14) I scale back all factor accumulation (CUDIE and human capital) or just CUDIE. If I use both physical and human in calculating TFP but scale back only CUDIE to be consistent with observed growth (assuming human capital was correctly measured and was productive), then the deviation between actual and implied growth of physical capital will be very large.

The results in Table 5 show the results of these calculations. Column 1 shows the actual per annum growth of per worker factors (CUDIE and human capital), and column 2 shows standard TFP. In column 3 we see that (for instance, in the Middle East and North Africa region) to be compatible with an assumption of zero TFP then, on average, "implied", factor growth could have been at most 1.62 percent - only 46 percent of the observed factor growth of 3.53 percent. If we assume that available TFP grew 1 percent per annum then factors could have grown at only 26 percent of the observed rate. Finally, if we assume that human-capital growth was correctly measured and that only CUDIE was overstated, then the growth rate and an assumption of zero TFP are compatible only with the physical capital stock having not increased at all over this period-in spite of the fact that CUDIE was 1.9 percent annum. ${ }^{22}$

The results are striking in a number of ways. First, the results suggest that in many regions the "implied" rate of factor accumulation was very, very much slower than the standard CUDIE (and human capital) estimates would suggest. In every developing region (except for East and "other" Asia) the implied rate of "capital" growth was only half (South Asia, Africa, MENA) to three-quarters (Latin America) as large as observed CUDIE growtheven when TFP growth was assumed to be zero. If the technical progress actually "available" to the economy grew by 1 percent per annum, then the implied capital growth was only a quarter or less of a actual in every region except in East Asia and the OECD. And if it is assumed that human capital was productive and that all of the mismeasurement is due to CUDIE alone, then in major regions of the world the implied productive capital stock did not growth at all in 30 years - in spite of substantial investment effort. 
Second, the results in Table 5 are striking in that they accord with my intuition of the effectiveness of public investment across countries. ${ }^{23}$ In the OECD and the high-performing Asian Economies (HPAE) there is very little difference, consistent with casual empiricism that these regions have had reasonably effective public sectors, in which, although there was perhaps pervasive corruption, at least things got done. The problems appear to be worse in regions where the fraction of investment that was public was high and, one suspected, efficacy low: the Middle East where governments invested huge oil revenues (even though the subsequent terms of trade shock on these economies and likely capital revaluation must be factored in); Sub-Saharan Africa (where Collier 1999 has recently documented the low returns to investments); and South Asia.

Third, it is also striking that there is no relationship between factor growth and the ratio of "implied" to actual factor growth (the cross country correlation is only -.19). Africa had both low investment effort (factor growth of 2 percent per annum) and apparently translated only a small fraction ( 49 percent) of that investment into "capital." In the MENA region there was no shortage of investment and factor growth was nearly as large as in the HPAE (3.5 percent versus 3.8 percent), but growth of "implied" factors was quite slow (1.6 percent).

My conjecture is that at least some of the difference between CUDIE growth and the "implied" capital growth is due to differences in investment efficacy $(\gamma)$, which are in turn determined by difference in constraints governments face from their citizens. Recently Sachs and Warner (1995) have proposed an indicator of overall policy that combines a binary indicator of whether or not a government is "repressive" and a binary indicator of a minimum amount of "openness" (nonrepressive and open governments are classified as having an "acceptable" policy environment). Table 6 shows the difference in the implied versus observed factor accumulation growth by whether regimes were politically repressive. Average factor growth was almost identical (2.14 versus 2.18 ). However, the "implied" rate of factor accumulation is 86 percent of the actual for the politically nonrepressive economies but only 50 percent for the repressive governments. Moreover, not only is the difference between observed and "implied" lower, suggesting on average lower efficacy in regressive regimes, but the variance of the difference is much higher for repressive regimes (1.9 vs. $.64){ }^{24}$ So while some repressive regimes might be quite effective at creating capital, others are very, very ineffective. The suggestive evidence is that the problem of low returns on investment is related to issues of governance, in the broad sense of government efficacy, not just economic policy.

These calculations are not "proof" that CUDIE does not measure capital; it simply demonstrates the implications of reversing the interpretation of slow growth from "low TFP in spite of capital accumulation" to "overstated capital accumulation." Even though there are no logical, theoretical or empirical grounds on which to do so, nearly all previous TFP calculations have taken CUDIE as an estimate of physical capital at face value. Except in circumstances one is willing to make the assumption that both the public sector and private sector are equally and fully effective in creating capital from investments ${ }^{25}$ the existing literature says nothing about a decomposition between "factors" and "productivity." Perpetual inventory methods do not create an estimate of available productive capital. Moreover, the discrepancy is not uniform but will be large for some countries (such as Tanzania) and small for others (such as the United States and Germany). 


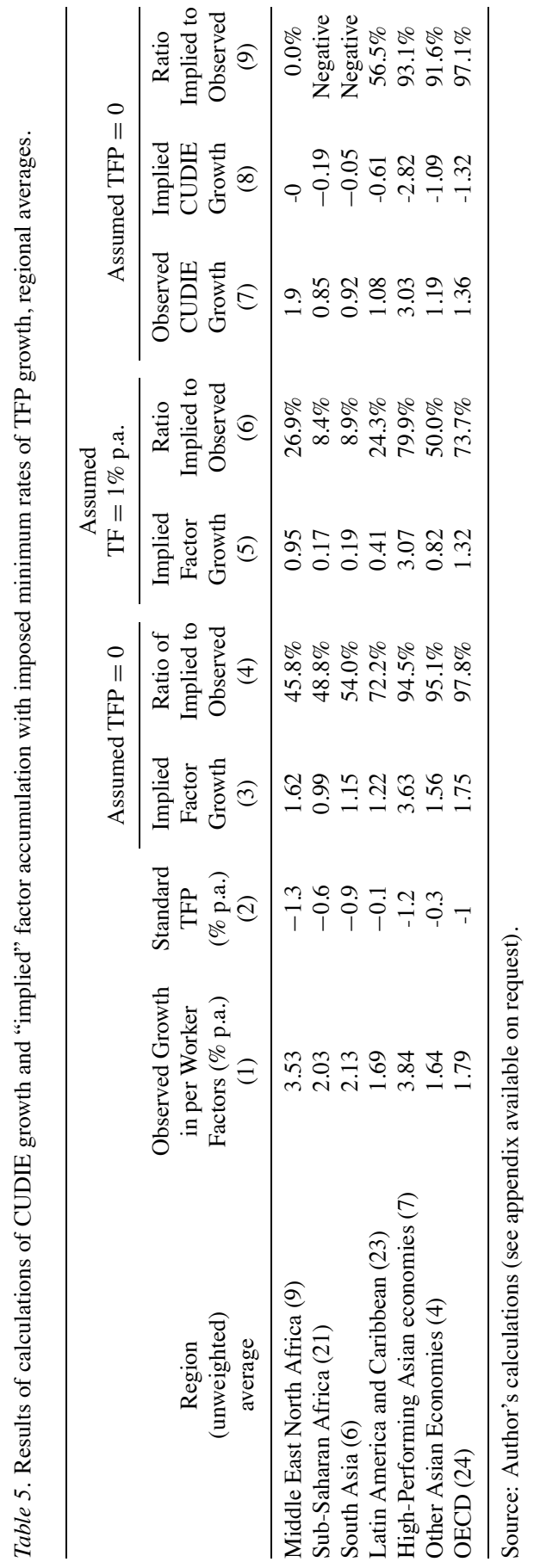


Table 6. Ratio of observed to implied factor accumulation (using assumptions of column 3 of Table 5), across types of countries.

\begin{tabular}{lccccc}
\hline \multicolumn{5}{c}{$\begin{array}{c}\text { Percent per Annum Growth } \\
\text { Factor Accumulation }\end{array}$} \\
$\begin{array}{l}\text { Country } \\
\text { Classification }\end{array}$ & $\begin{array}{c}\text { Number of } \\
\text { Countries }\end{array}$ & Observed & Implied & Ratio & $\begin{array}{c}\text { Standard Deviation of } \\
\text { the Difference }\end{array}$ \\
\hline $\begin{array}{l}\text { Nonrepressive } \\
\text { Repressive }\end{array}$ & 56 & 2.14 & 1.84 & $86.0 \%$ & 0.69 \\
$\begin{array}{l}\text { Acceptable } \\
\text { policies }\end{array}$ & 38 & 2.18 & 1.08 & $49.5 \%$ & 1.9 \\
"Bad" policies & 66 & 2.27 & 2.15 & $94.7 \%$ & 0.46 \\
\hline
\end{tabular}

Sources: Table 5, column 3, for factor accumulation estimates (Sachs and Warner, 1995).

The ubiquity of this logical inconsistency is well illustrated by the recent paper of Hall and Jones (1999) - two of the world's premier macroeconomists. In their paper they postulate that "social infrastructure," which is measured by elements of government performance (such as corruption) and policies (especially "openness"), affects output per worker. They then decompose output into "capital" and "productivity" using perpetual inventory capital stocks. Using this capital stock they show the proportions of output differences across countries due to various sources (their Table 1) and even illustrate the channels, which decomposes the effect of "social infrastructure" into its impact on "capital" and its impact on "productivity" $(\ln A)$. However, it is simply logically inconsistent to postulate that characteristics of governments affect output, given capital stocks, but do not affect the output of capital goods for a given amount of investment. If one eliminates that logical inconsistency and assumes that government "productivity" affects factor accumulation, then one cannot separately identify as they do the portion of output due to factors and factor productivity across countries.

\section{Growth Regressions}

The fact that CUDIE differs from capital systematically across countries has two implications for the interpretations of existing growth regressions.

First, having controlled for CUDIE is not the same as having controlled for capital. This implicit "omitted variables bias" potentially affects all other growth regression coefficients. The deviation of actual capital from CUDIE is country (and time) specific and is endogenously determined and hence is unlikely to be orthogonal to other covariates. Take a regression of growth $(y)$ on CUDIE $(c)$ and some other potential growth determinant, $X$. The typical regression is

$$
y_{i}=\alpha \bar{\gamma} * c_{i}+\beta * X_{i} \varepsilon_{i} .
$$

However, since the cross-national regressions almost invariably impose constant coefficients, this means that the error term will contain an "omitted variable" for varying efficacy:

$$
\varepsilon_{i}=v_{i}+\left[\gamma_{i}-\bar{\gamma}\right] * c_{i} .
$$


As usual the direction of the "omitted variable" bias will be difficult to sign in a multivariate context but will depend on the correlation between the included variables $(x)$ and the omitted variable. The only correct interpretation of such regressions is: "impact of variable $X$ conditional on CUDIE" not the "impact of variables $X$ conditional on capital stock growth."

Second, this inability to estimate factor growth also implies that all attempts to empirically decompose a variables impact on growth into its "factor accumulation" effects and its "productivity" effects is doomed from the outset. In investigations of the channels of impact, researchers should be clear that what is estimated is the "impact of $X$ on growth via investment effort or CUDIE" and the "impact of $X$ on growth, conditional on investment effort or CUDIE." This would again make it clear that the decomposition is not into what is normally conceived of as the concepts of "capital" and "TFP" but in "CUDIE" and a "residual term that also contains deviations of CUDIE from capital"-including a portion determined by the efficacy of investment (as well as revaluation, and so forth).

To some extent this is reassuring, relative to the previous interpretations of the residual actually reflecting TFP. In many cases researchers regressed the residual of a growth regression (or a constructed TFP using imposed factor shares) on underlying "determinants" of TFP. However, as Hall (1989) pointed out, strictly speaking, within the Solow growth model TFP should be orthogonal to all kinds of r.h.s. variables representing "incentives." Since factor payments exhaust product, there should be no opportunity for incentives to affect TFP. However, if the residual is correctly interpreted as reflecting (1) technical progress (fundamental progress in knowledge), (2) changes in efficiency with which capital stocks (human and physical) are used, and (3) the efficacy of past investments in creating capital useful for current period production, then it need not be orthogonal. Many of the existing "TFP" results are more easily understood in this light.

For example, how does one interpret a growth regression that includes both CUDIE and "quality of bureaucracy" (as well as human capital, and what not)? The existing interpretations seem to imply that bureaucracy has an impact on output controlling for factor accumulation and hence that this governance term affects the efficacy with which factors are used. However, it is equally plausible that the "quality of bureaucracy" term is picking up the fact that CUDIE does not reflect capital accumulation but only investment spending. Where the quality of bureaucracy is low, then CUDIE created little capital. Therefore, there is no way to say the impact of the quality of bureaucracy reflects the efficiency of the use of existing factors versus reflecting that few factors are created by investment spending when the quality of bureaucracy is low. A similar problem of interpretation arises for any variable correlated with government efficacy of investment.

\section{Conclusion}

All of the recent spate of empirical research on growth using investment or capital has implicitly assumed that all governments everywhere were always cost minimizing investors. This is obviously false. Cross-national empirical research using investment rates or CUDIE cannot be used to make statements such as "the estimated impact of public capital is ..." or "the contribution of output due to capital is ..." or "the portion of output growth not accounted for by differences in factor accumulation is ..." 
This is not an arcane quibble but is empirically important and has serious policy and theoretical implications. If one concludes that the "productivity of public capital is low," this has different implications for government investment policy than "the output impact of CUDIE is low." When stated correctly, it is apparent the impact of CUDIE might have been low because of low investment efficacy, because of inadequate maintenance and hence high depreciation, because of larger ex post shifts in relative prices, or because of poor efficiency of the operation of capital in the public sector. Each of these has different policy implications than low productivity of public capital. The fact recorded government investment spending of various types may or may not be associated with better economic performance is an interesting fact but by itself provides little useful information for policy recommendations.

Similarly, if one concludes "capital does not account for a large fraction of cross national output differences," this suggests certain theoretical directions, such as research into differences in "technical progress," "technological diffusion," or "efficiency." If, however, the actual empirical result is stated more prosaically, and more accurately, as "differences in what governments run by corrupt autocrats/oligarchs/dictators spent in the past and was recorded as investment does not explain current output," this suggests very different lines of research, approaches that are much more likely to be fruitful in understanding cross-national differences in levels and growth rates of output.

I would propose that we begin the end of this tyrannical reign of conceptual confusion: lets call capital, capital and let's call CUDIE, CUDIE.

\section{Acknowledgments}

I would like to thank Bill Easterly, Deon Filmer, Jonah Gelbach, Aart Kray, Ross Levine, Norman Loayza, Allison Morantz, Vikram Nehru, Moshe Syrquin, Vinaya Swaroop, Mike Walton, and the participants at seminars at the World Bank and the Council of Economic Advisors for useful comments and discussions. Dennis Tao was very helpful at a critical stage of this project. This article draws heavily on an earlier paper of mine, "Mind Your p's and q's: The Cost of Public Investment Is Not the Value of Public Capital." As for the title, I would like to remind Alwyn Young of the sincerest form of flattery.

\section{Notes}

1. We did not visit the infamous white elephant - the Morogoro shoe factory - because we were told the expatriate manager was in therapy, depressed from so many visitors trooping through.

2. In fact, this may explain the relatively slower growth of the natural-resource-dependent economies, conditional on their rates of investment (Sachs and Warner, 1995). What looks like slow TFP growth using capital stocks based on investment flows may really be that massive investments made by governments in resource extraction industries turned out to have very low returns. One possible way of getting at this phenomenon would be to examine the evolution of the stock-market valuation of the equity of resource-based firms as commodity prices shift. Perhaps this could lead to some useful way to estimate the revaluation of capital impact of terms of trade shifts on Zambia's copper mines or Bolivia's tin mines or Cote d'Ivoire's cocoa plants. 
3. One factor I am ignoring, so as to not complicate the story line, is that government depreciation of assets may be much more rapid than in the private sector. Similar to the cost argument, there are widespread of examples of government not making optimal (or even reasonable) investments in maintenance and hence leading to a rapid depreciation of assets. See Easterly (1999) for one explanation of the phenomenon. Incorporating this point would strengthen all the arguments in the article about the inadequacy of CUDIE as a proxy for capital.

4. The cross-national capital stock series include those created from World Bank investment data (Nehru and Dhareshwar, 1993) and many created from the Penn World Tables National Accounts data, including King and Levine (1994). The creation of these series is so easy many people just create their own "capital" series for a paper. I have to confess I have done that (Pritchett, 1996), as have as Hall and Jones (1999), Easterly (1999), and many others.

5. I don't even address the common procedure of using $I$ or $I / Y$ as a proxy for capital stock growth. Not only does this share all of the problems described here with CUDIE, but, as it turns out, $I / Y$ is not even a good proxy for CUDIE growth. As I have shown elsewhere, the rate of growth of CUDIE is uncorrelated with $I / Y$ in CUDIE constructed from either World Bank (Nehru and Dhareshwar, 1993) or Penn World Tables (King and Levine, 1994) data. This has the obvious implication that, while $I / Y$ is typically a significant growth regressor and CUDIE growth is typically a significant growth regressor, it is also the case that including both variables in a growth regression produces almost exactly the same coefficient on each as when they are each included singly. I regard this as something of a puzzle (and one that does not seem to have been noticed). But whatever role it plays, $I / Y$ is not serving as a proxy for CUDIE growth.

6. These can lead to variations in performance. Isham, Kaufman, and Pritchett (1996) show that countries with greater civil liberties have higher returns on World Bank-financed investment.

7. The existence of multiple providers is, of course, itself an endogenous outcome of the interaction of government and citizens but an outcome that at least part of "government" can be expected to resist.

8. There was a hilarious Saturday Night Live sketch in which a Ross Perot impersonator offered just such a deal as a presidential candidate: "Hey, economy grows three percent I get nothing. Anybody could do that. But hey, say the economy grows four percent. Then I get one billion dollars. Now, say the economy grows five percent. ...'

9. Broadly speaking, one could call the control of citizens the degree of government accountability. This is a common feature of focus on public-sector incentives links many current strands of development literature, including: talk of governance and accountability, the treatment of infrastructure in the 1994 World Development Report (which focused on the internal organization of infrastructure providers), the talk of "reinventing government" in the United States (Osborne and Gaebler, 1992), discussions of participation as a means of improving public performance (Isham, Narayan, and Pritchett, 1995), estimates of the relationship between returns on investment and civil liberties (Isham, Kaufmann, and Pritchett, 1996), and the work on the features of the public sector in East Asia (Campos and Root, 1996).

10. The ex post return is assessed after disbursement of the World Bank loan. Also, these are economic not financial returns to investment, so that they do, at least in theory, value nonmarketed outputs (such as roads).

11. I'll ignore the whole literature in the United States and the debate between Aschauer (1989), who finds returns around 60 percent, and Holtz-Eakin (1992), who finds returns around 0.

12. The two qualifications in the sentences are important: "private good" so that prices really could be charged and "competitive environment" because many of the most lucrative privatizations are those that sell monopolies, like telecommunications firms, where the price paid for accumulated assets is difficult to disentangle from the price paid for the exclusive franchise.

13. Although this is not certain, as the assets themselves may be in declining industry and there might be discounts due to asset specificity.

14. It would be naive to be "surprised," as for governments to admit they are selling firms for a fraction of what they paid for them is obviously embarrassing and hence best left undocumented. But all the more reason it would have a high payoff to document.

15. Using a Solow-type production function for the example hopefully does not create confusion that this is about "new" versus "old" growth models or a "spilllovers" versus "direct productivity" issue of modeling public capital or anything other issue about the assumed functional form of the production function. When it comes to empirics, one way or another public capital $K_{g}$ will enter some production function specification - but that $K_{g}$ will be badly measured.

16. Using investment shares, one needs to divide by the capital/output ratio to recover the production function parameter, but the same lack of identification applies. 
17. Hulten (1996) does similar regressions within the context of a extended Solow model in which the coefficients on public and private investment are treated as production function parameters. He uses estimates of physical infrastructure and quality of that infrastructure. His paper however treats only limited infrastructure items and does not make the general point about identification of investment efficacy in the government sector or the implications for measured TFP.

18. Exceptions are Canning and Fay (1996) and Hulten (1996), who attempt to estimate infrastructure productivity using data on actual stock (such as phone lines and miles of road), although even here, they recognize, one must adjust for quality and actual usable stock.

19. The case of low efficacy is common in the developing countries reconciles a common paradox. For decades development "experts" have observed the lack of roads, power, schools, and health clinics and assumed that since the stock was so low, the marginal product of public-sector capital must be high and hence "more investment" was the appropriate answer. However, this has left a legacy in the poorest countries of large amounts of public-sector investment (often with official financing) but with little or no public-sector capital to show for it.

20. This also reenforces the point made by Easterly (1999b) that the continued common use of ICORs as a measure of "efficiency" and "investment" as a causally driving force to growth is absurd and should be stopped.

21. The problem with of coping with fluctuations (both cyclical and due to shocks) is so severe I do not pursue TFP measurement over shorter periods.

22. Zero is an obvious lower bound as Bernard and Jones (1996) point out steady-state TFP cannot be negative.

23. See Bosworth, Collins, and Chen (1995) for an excellent discussion and implementation of the various issues involved in this type of "growth accounting" estimate of TFP. The regional pattern of their preferred TFP estimates (in spite of the different data, regional coverage, and time period) are similar to the TFP reported in Table 5-SSS -.7, MENA - .4. LAC .1, OECD 1.0, East Asia .8, South Asia .7.

24. The difference between repressive and nonrepressive is robust whether one excludes Africa (mostly classified as repressive) or the OECD all (nonrepressive) from the calculations.

25. In addition, of course, to assuming away of relative price shift induced revaluations, mistakes, terms of trade changes, obsolesce, excess depreciation.

\section{References}

Aschauer, David. (1989). “Is Public Expenditure Productive?” Journal of Monetary Economics 23, 177-200.

Benhabib, Jess, and Mark Spiegel. (1994). "Role of Human Capital in Economic Development: Evidence from Aggregate Cross-Country Data." Journal of Monetary Economics 34, 143-173.

Bernard, Andrew B., and Charles I. Jones. (1996). “Technology and Convergence." Economic Journal 106, 1037-1044.

Boskin, Michael, J., Marc Robinson, and John M. Roberts. (1985). "New Estimate of Government Tangible Capital and Net Investment.” NBER Working Paper Series No. 1774.

Bosworth, Barry, Susan Collins, and Yu-chin Chen. (1995). "Accounting for Differences in Economic Growth." Mimeo, Brookings.

Boycko, Maxim, Andrei Shliefer, and Robert Vishny. (1993). "Privatizing Russia." Brookings Papers on Economic Activity 2, 139-192.

Campos, Edgardo, and Hilton Root. (1996). The Key to Asian Miracle: Making Shared Growth Credible. Washington, DC: Brookings.

Canning, David, and Marianne Fay. (1996). "Infrastructure and Growth.” Mimeo.

Charap, Joshua, and Christian Harm. (1999). "Institutionalized Corruption and the Kleptocratic State." IMF Working Paper.

De Long, J. Bradford, and Lawrence H. Summerss (1992). "Equipment Investment and Economic Growth: How Strong Is the Nexus?" Brookings Papers on Economic Activity 2, 157-211.

Easterly, William (1999). "When Is Fiscal Adjustment an Illusion?" World Bank Policy Research Working Paper No. 2109.

Easterly, William. (1999b). "The Ghost of Financing Gap: Testing the Growth Model Used in the International Financial Institutions.” Journal of Development Economics 60, 423-438. 
Easterly, William, and Sergio Rebelo. (1993). "Fiscal Policy and Economic Growth: An Empirical Investigation." Journal of Monetary Economics 32, 417-458.

Hall, Robert E. (1989). "Invariance Properties of Solow's Productivity Residual.” In Robert M. Solow and Peter Diamond. Growth, Productivity, Unemployment: Essays to Celebrate Bob Solow's Birthday. Cambridge, MA: MIT Press.

Hall, Robert E., and Charles Jones. (1999). "Why Do Some Countries Produce So Much More Output per Worker Than Others?" Quarterly Journal of Economics 114, 83-116.

Hayek, Friedrich A. (1941). The Pure Theory of Capital. Chicago: University of Chicago Press.

Holtz-Eakin, Douglas. (1992). "Public Sector Capital and the Productivity Puzzle." NBER Working Paper No. 4122.

Hulten, Charles R. (1996). "Infrastructure Capital and Economic Growth: How Well You Use It May Be More Important Than How Much You Have.” NBER Working Paper No. 5847.

Isham, Jonathan, Daniel Kaufmann, and Lant Pritchett. (1996). "Governance and the Returns to Investment: An Empirical Investigation.” World Bank Policy Research Paper No. 1550.

Isham, Jonathan, Deepa Narayan, and Lant Pritchett. (1995). "Does Participation Improve Performance? Establishing Causality with Subjective Data.” World Bank Economic Review 9, 175-201.

Islam, Nazrul. (1995). "Growth Empirics: A Panel Data Approach.” Quarterly Journal of Economics 110, $1127-1170$

Jaffe, Adam. (1986). “Technological Opportunity and Spillovers of R\&D: Evidence from Firms’ Patents, Profits, and Market Value.” NBER Working Paper No. 1815.

Joshi, Vijay, and I.M.D. Little. (1994). India: Macroeconomics and Political Economy, 1964-1991. Washington, DC: World Bank.

Keefer, Philip, and Stephen Knack. (1997). "Why Don't Poor Countries Catch Up? A Cross-National Test of an Institutional Explanation.” Economic Inquiry (U.S) 35, 590-602.

King, Robert G., and Ross Levine. (1994). "Capital Fundamentalism, Economic Development, and Economic Growth." Carnegie-Rochester Conference on Public Policy 40, 259-292.

Mauro, Paolo. (1998). "Corruption and the Composition of Government Expenditure." Journal of Public Economics 69, 263-279.

Milgrom, Paul R., and John Roberts. (1992). Economics, Organization, and Management. Edgewood Cliffs, NJ: Prentice-Hall.

Nehru, Vikram, and Ashok Dhareshwar. (1993). "A New Database on Physical Capital Stock: Sources, Methodology and Results.” Revista de Analisis Economico 8, 37-59.

Osborne, David, and Ted Gaebler. (1992). Reinventing Government: How the Entrepreneurial Spirit is Transforming the Public Sector. New York: Plume, Penguin Books.

Pritchett, Lant. (1996). "Where Has All the Education Gone?" World Bank Policy Research Working Paper No. 1581.

Rajaiah, B. (1989). Returns to Investment and Efficiency in Public Enterprises in India. Delhi: Mittal.

Sachs, Jeffrey, and Andrew Warner. (1995). "Economic Reform and the Process of Global Integration.” Brookings Papers on Economic Activity 1, 1-118.

Shah, Anwar. (1992). "Dynamics of Public Infrastructure, Industrial Productivity, and Profitability." Review of Economics and Statistics 74, 28-36.

Shleifer, Andrei. (1993). “Corruption.” Quarterly Journal of Economics 108, 599-617.

Shleifer, Andrei, and Robert W. Vishny. (1998). "The Grabbing Hand: Government Pathologies and Their Cures." Cambridge, MA: Harvard University Press.

Uchimura, Kauko, and Jong Gao. (1993). “The Importance of Infrastructure on Economic Development.” World Bank, Latin American Regional Office, Washington, DC. 